DOI https://doi.org/10.36059/978-966-397-155-1/62-79

\title{
CHARACTERISTICS OF THE NETWORK OF HEALTH CARE INSTITUTIONS AND PERSONNEL OF THE TRANSCARPATHIAN REGIONAL HEALTH CARE SYSTEM
}

\author{
Danko D. V.
}

\section{INTRODUCTION}

The main strategic goals of the health care system are preserving and improving the health of the population, enhancing the quality of medical care, as well as developing specific medical preventive measures, forms and methods of work of specialized services. The attainment of these goals is impossible without developing effective health care institutions network and providing skilled personnel. To make sound management decisions at all levels, including the regional level, it is necessary to conduct a thorough analysis of both the availability and use of all health care resources, including the network of institutions and the supply of qualified medical personnel.

In the current conditions, consistent work is being done to optimize and further develop the network of health care facilities delivering all types of medical care within the health care system of Ukraine ${ }^{1}$.

This is facilitated by the existence of a comprehensive health care system in the country that has been operating for about ten years, and its activities have been refined in pilot regions ${ }^{2}{ }^{3}$.

At present the reform of the health care system in Ukraine involves restructuring of the system with the priority of the development of primary

\footnotetext{
${ }^{1}$ Stratehichna doradcha hrupa z pytan reformuvannia systemy okhorony zdorovia v Ukraini (2015) Natsionalna stratehiia reformuvannia systemy okhorony zdorovia v Ukraini na period 2015-2020 rokiv [National Health Care Reform Strategy in Ukraine for the period of 20152020], pp. 41. Retrived from: http://healthsag.org.ua/strategiya/

${ }^{2}$ Lekhan V.M., Slabkyi H.O., Shevchenko M.V. (2015) Analiz rezultativ reformuvannia systemy okhorony zdorovia $\mathrm{v}$ pilotnykh rehionakh: pozytyvni naslidky, problemy ta mozhlyvi shliakhy yikh vyrishennia [Analyzing health reform outcomes in pilot regions: positive impacts, challenges, and possible solutions]. Zdorovia natsii, vol. 3 (Special issue), pp. 67-86.

3 Slabkyi H.O., Lekhan V.M. (2015) Uroky reformy okhorony zdorovia v Ukraini: dosiahnennia, nevyrisheni pytannia, ryzyky, problemy [Healthcare reform lessons in Ukraine: achievements, unresolved issues, risks, challenges]. Proceedings of the International Conference "Orhanizatsiia i upravlinnia okhoronoiu zdorovia" (Ukraine, October 20-21, 2015), pp. 26-27.
} 
medical health care based on general practice/family medicine (primary (care) ${ }^{4}$, in which there is the benefit of free choice of family doctors on the one hand ${ }^{5}$ and family doctors determine the patients' clinical pathways on the other ${ }^{6}$. At the level of specialized medical care Formation of hospital districts with the formation of intensive care hospitals is envisaged ${ }^{7}$. Also, a qualitatively new medical professional training system with continuous professional development will be introduced ${ }^{8}$.

Fundamentally new to the healthcare system of Ukraine is the introduction of a guaranteed package of medical services on the principle of «money follows the patient ${ }^{9}$, as well as the autonomy of healthcare institutions ${ }^{10}$.

The reform process is implemented step by step and allows to improve different elements and levels of health care work and medical care technologies, to introduce new organizational forms and accumulate the necessary resources.

${ }^{4}$ Slabkyi H. O., Zozulia I.S., Zozulia A.I. (2014) Priorytetnyi rozvytok pervynnoi medykosanitarnoi dopomohy na zasadakh simeinoi medytsyny [Priority development of primary health care based on family medicine]. Simeina medytsyna, vol. 3, No. 53, pp. 25-27.

5 Lekhan V. M., Nadutyi K.O., Slabkyi H.O. (2011) Innovatsiini pidkhody do zabezpechennia dostupnosti pervynnoi medyko-sanitarnoi dopomohy silskomu naselenniu [Innovative approaches to ensuring the availability of primary health care to the rural population]. Zdorovia natsii, vol. 3, No. 19, pp. 86-91.

${ }^{6}$ Matiukha L.F., Lekhan V.M., Hoida N.H. et al. (2011) Poriadok orhanizatsii nadannia medychnoi dopomohy ta zabezpechennia marshrutiv patsiienta likarem zahalnoi praktyky simeinym likarem pry riznykh klinichnykh stanakh ta zakhvoriuvanniakh [The procedure for the organization of care and providing pathways by a general practitioner - family physician in different clinical conditions and diseases]. Ministry of Health of Ukraine; National Medical Academy of Post-Graduate Education named after P. L. Shupyk, Ukrainian Institute for Social Research, Dnipropetrovsk State Medical Academy, Zaporizzhia Medical Post-Graduate Academy, Chernivtsi Health Care Department, p. 43.

${ }^{7}$ Parkhomenko H. Ya. (2011) Likarnia intensyvnoi dopomohy - likarnia yevropeiskoho zrazka [Intensive care hospital - a European-style hospital]. Visnyk sotsialnoi hihiieny ta orhanizatsii okhorony zdorovia Ukrainy, vol. 2, pp. 39-41.

${ }^{8}$ Kotenko S.L. (2015) Derzhavne rehuliuvannia kadrovoi polityky haluzi okhorony zdorovia [State regulation of the personnel policy of the health care industry]. Proceedings of the naukovo- Proceedings of the Conference "Zavdannia derzhavy u zabezpechenni efektyvnoi kadrovoi polityky systemy okhorony zdorovia" (Ukraine, Kyiv, April 22, 2015), pp. 56-59.

${ }^{9}$ Zakon Ukrainy vid 19 zhovtnia 2017 roku 2168-VIII (2017) Pro derzhavni finansovi harantii medychnoho obsluhovuvannia naselennia [Law of Ukraine On State Financial Guarantees of Public Health Services: Law of Ukraine of October 19, 2017 No. 2168-VIII]. Retrieved from: http://search.ligazakon.ua/l_doc2.nsf/link1/T172168.html

${ }^{10}$ Skryp V. V., Slabkyi H.O. (2015) Metodychni pidkhody do avtonomizatsii zakladiv okhorony zdorovia [Methodological approaches to the autonomy of health care institutions]. Intermedical Journal, vol. IV, No. 6, pp. 20-25. 
In this regard, there is a need for further improvement of the health care system organization and management. It is necessary to promote the optimization and restructuring of health care institutions network, prioritize the development of the primary care based on general practice/family medicine and emergency medical care, the formation of rehabilitation and palliative care facilities network, and the introduction of modern medical technologies of prevention, diagnostics, treatment, and rehabilitation.

In the context of the priority of primary care development and preparation for specialized and highly specialized medical care reform, it was found expedient to study and conduct a comprehensive system analysis of providing medical care to the population of the Transcarpathian region of Ukraine. It is a mountainous region, in which population is distributed according to the following geographical areas: flatland, foothill and mountainous zones ${ }^{11}$.

\section{Characteristics of health care institutions network in the Transcarpathian region}

The analysis of the network of the health care institutions in the Transcarpathian region was conducted using data from the Department of Health of the Transcarpathian Regional State Administration for the period of $2014-2018^{12}$. $^{13}$

The initial phase of the study included the analysis of the overall network of health care institutions/ separate subdivisions of the Transcarpathian region, with the population numbers in the administrative territories as of the end of 2018 (Table 1), followed by its comparison with 2014 and 2017 data.

11 Rohach I.M., Danko D.V. (2019) Kharakterystyka naselennia Zakarpatskoi oblasti [Characteristics of the population of the Transcarpathian region]. Ekonomika i pravo okhorony zdorovia, vol. 1, No. 9, pp. 75-78.

12 Zakarpatskyi oblasnyi medychnyi informatsiino-analitychnyi tsentr (2015) Merezha zakladiv ta osnovni pokaznyky diialnosti systemy okhorony zdorovia Zakarpatskoi oblasti za 2014 rik.[Network of institutions and key indicators of health care system activity in Transcarpathian region for 2014] Uzhhorod: Zakarpatskyi oblasnyi medychnyi informatsiinoanalitychnyi tsentr.

${ }^{13}$ Zakarpatskyi oblasnyi medychnyi informatsiino-analitychnyi tsentr (2019) Merezha zakladiv ta osnovni pokaznyky diialnosti systemy okhorony zdorovia Zakarpatskoi oblasti za 2018 rik [The network of institutions and key indicators of the health care system of Transcarpathian region for 2018] Uzhhorod: Zakarpatskyi oblasnyi medychnyi informatsiinoanalitychnyi tsentr. 
Table 1

General network of health care institutions/subdivisions of the Transcarpathian region with the number of population in administrative territories, 2018

\begin{tabular}{|c|c|c|c|c|c|c|c|c|c|c|c|c|c|c|}
\hline $\begin{array}{c}\text { Adminis- } \\
\text { trative } \\
\text { territories }\end{array}$ & 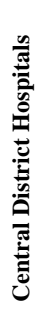 & 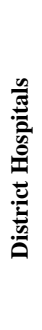 & 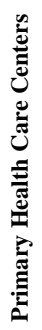 & 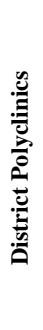 & 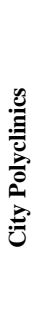 & 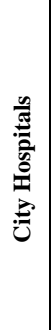 & 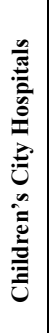 & 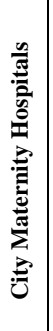 & 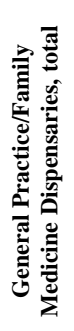 & 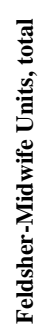 & 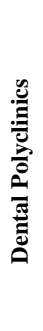 & 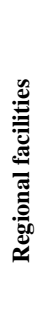 & 吾 & 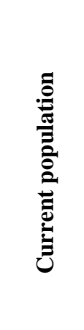 \\
\hline \multicolumn{15}{|c|}{ Districts } \\
\hline $\begin{array}{c}\text { Berehove } \\
\text { district }\end{array}$ & 1 & - & 1 & - & - & - & - & - & 24 & 19 & - & - & 45 & 74949 \\
\hline $\begin{array}{c}\text { VelykyiBer } \\
\text { eznyi } \\
\text { district }\end{array}$ & - & 1 & 1 & - & - & - & - & - & 9 & 24 & - & - & 365 & 26414 \\
\hline $\begin{array}{c}\text { Vynohradiv } \\
\text { district }\end{array}$ & - & 1 & 1 & - & - & - & - & - & 35 & 16 & - & - & 53 & 121187 \\
\hline $\begin{array}{l}\text { Volovets } \\
\text { district }\end{array}$ & 1 & - & 1 & - & - & - & - & - & 5 & 23 & - & - & 30 & 24175 \\
\hline $\begin{array}{l}\text { Irshava } \\
\text { district }\end{array}$ & - & 1 & 1 & - & - & - & - & - & 33 & 11 & 1 & - & 47 & 100493 \\
\hline $\begin{array}{c}\text { Mizhhiria } \\
\text { district }\end{array}$ & - & 1 & 1 & - & - & - & - & - & 17 & 20 & - & - & 39 & 47715 \\
\hline $\begin{array}{c}\text { Mukachevo } \\
\text { district }\end{array}$ & 1 & - & 2 & - & - & - & - & - & 36 & 45 & - & - & 84 & 186352 \\
\hline $\begin{array}{c}\text { Perechyn } \\
\text { district }\end{array}$ & 1 & - & 2 & - & - & - & - & - & 9 & 13 & - & - & 25 & 31936 \\
\hline $\begin{array}{l}\text { Rakhiv } \\
\text { district }\end{array}$ & - & 1 & 1 & - & - & 2 & - & - & 25 & 8 & - & - & 37 & 92814 \\
\hline $\begin{array}{c}\text { Svaliava } \\
\text { district }\end{array}$ & 1 & & 2 & - & - & & - & - & 14 & 11 & - & - & 28 & 54628 \\
\hline $\begin{array}{l}\text { Tiachiv } \\
\text { district }\end{array}$ & - & 2 & 3 & 1 & - & 2 & - & - & 36 & 25 & 1 & - & 74 & 175478 \\
\hline $\begin{array}{c}\text { Uzhhorod } \\
\text { district }\end{array}$ & - & 1 & 2 & - & - & - & - & - & 28 & 29 & - & - & 60 & 71635 \\
\hline $\begin{array}{c}\text { Khust } \\
\text { district }\end{array}$ & - & 1 & 1 & 1 & - & - & - & - & 27 & 16 & 1 & - & 47 & 127434 \\
\hline \multicolumn{15}{|c|}{ Cities } \\
\hline Uzhhorod & - & - & 1 & - & 1 & 1 & 1 & 1 & 9 & - & - & - & 14 & 113996 \\
\hline Chop & - & - & 1 & - & - & 1 & - & - & 1 & - & - & - & 3 & 8949 \\
\hline Additional & - & - & - & - & - & - & - & - & - & - & - & 25 & 25 & - \\
\hline Total & 5 & 9 & 21 & 2 & 1 & 6 & 1 & 1 & 308 & 260 & 3 & 25 & 646 & 1258155 \\
\hline
\end{tabular}


The analysis of the data presented in Table 1 indicates that the Transcarpathian region has an extensive network of health care institutions and separate structural units of primary, specialized and highly specialized medical care. In addition to the health facilities listed in the table, there are 4 community hospitals in Tiachiv district. In total there are 646 health facilities and their separate subdivisions in the region. $91.18 \%$ of health care institutions /separate units provide primary health care, $4,95 \%$ specialized health care, and $3.87 \%$ highly specialized medical care. However, the number of health care institutions in the region's administrative territories and the number of the population living in these territories do not correlate.

The number of health care institutions and their separate structural divisions has increased by 16 compared with 2014. However, it has decreased by 5 compared with 2017. The largest structural changes in the health care institutions network have occurred due to an increase in the number of General Practice/Family Medicine Dispensaries (GPFMD) by 33 and a decrease in the number of Feldsher-Midwife Units (FMU) by 20 in comparison with 2014.

The network of institutions/separate structural divisions of primary health care was analyzed in detail according to the region's geographical zones. There are the following geographical zones in the region: flatlands, foothill areas and mountain areas. The data obtained are shown in Table. 2.

The analysis of the data presented in Table 2 indicates that the regional primary health care system was fully formed in 2018. Its facilities are legally delimited with specialized health care facilities regardless of the region's geographical zones. For this purpose, Primary Health Care Centers (PHCC), which included GPFMD and FMU were established in all administrative territories. The total number of GPFMD is 308, out of these 48 GPFMD $(15.58 \%)$ operate in cities and $260(84.42 \%)$ in rural areas. The total number of FMU is $260.38(14.62 \%)$ of them are located in villages with the population of more than 1000 people.

In accordance with the current regulations, GPFMD should be formed and general practice/family medicine (GP/FM) positions should be introduced in health care units in these administrative territories.

The number of GPFMD correlates with the population numbers in all administrative territories, except for the city of Uzhhorod.

The number of PHCC increased by 10 in comparison with 2014. The new centers include 6 that were established in the newly formed territorial communities. The number of GPFMD increased by 33. All the independent primary health care structural units and the ones that were part of the specialized health care institutions are included in the PHCC. 
Table 2

Network of health care institutions / separate units of primary health care of the Transcarpathian region in the context of administrative territories and geographical zones, 2018

\begin{tabular}{|c|c|c|c|c|c|c|c|}
\hline $\begin{array}{c}\text { Administrative } \\
\text { territories, } \\
\text { geographical zones }\end{array}$ & $\begin{array}{c}\text { Primary } \\
\text { Health } \\
\text { Care } \\
\text { Centers }\end{array}$ & $\begin{array}{c}\text { General } \\
\text { Practice/ } \\
\text { Family } \\
\text { Medicine } \\
\text { Dispen- } \\
\text { saries }\end{array}$ & $\begin{array}{c}\text { General Practice/ } \\
\text { Family Medicine } \\
\text { Dispensaries }\end{array}$ & $\begin{array}{c}\text { Felds } \\
\text { her- } \\
\text { Mid } \\
\text { wife }\end{array}$ & $\begin{array}{c}\text { Feldsher- } \\
\text { Midwife } \\
\text { Units in } \\
\text { villages } \\
\text { with the } \\
\text { population } \\
\text { over 1000 }\end{array}$ \\
\hline \multicolumn{7}{|l|}{ Flatland zone } \\
Units
\end{tabular}

The next step in the study was to examine the health care facilities network in the Transcarpathian region according to geographical zones and analyze it in comparison with 2014. The data obtained are shown in table 3.

According to the data in table 3 , there are specialized medical care facilities in each administrative territory in the region that provide both outpatient and inpatient medical care; however, they differ structurally. Thus, there are central district hospitals $(\mathrm{CDH})$ in five districts, district hospitals $(\mathrm{DH})$ in nine districts, city hospitals $(\mathrm{CH})$ in two districts, district polyclinics in two districts and dental polyclinics in three districts. It should be noted that there are two city hospitals in both Tiachiv and Rakhiv districts respectively. Also, there are four community hospitals in Tiachiv district, while Children's Hospital, which provides specialized medical care, operates only in Uzhhorod. 


\section{Table 3}

\section{Network of Health Care Institutions that Provide Specialized Medical Assistance in Transcarpathian Region in the context of Administrative Territories and Geographical Zones, 2018}

\begin{tabular}{|c|c|c|c|c|c|c|c|c|}
\hline $\begin{array}{l}\text { Administrative } \\
\text { territories, } \\
\text { geographical zones }\end{array}$ & ชิ & $\overline{\mathbf{D}}$ & 苞 & 色 & 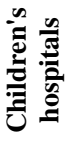 & 离品 & 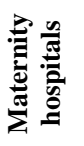 & 焉 \\
\hline \multicolumn{9}{|c|}{ Flatland zone } \\
\hline Uzhhorod city & - & - & 1 & 1 & 1 & - & 1 & - \\
\hline Chop city & - & - & 1 & - & - & - & - & - \\
\hline Berehove district & 1 & - & - & - & - & - & - & - \\
\hline Vynohradiv district & & 1 & - & - & - & - & - & - \\
\hline Mukachevo district & 1 & - & - & - & - & - & - & - \\
\hline Uzhhorod district & $\alpha$ & 1 & - & - & - & - & - & - \\
\hline \multicolumn{9}{|c|}{ Foothill zone } \\
\hline Irshava district & - & 1 & - & - & - & - & - & 1 \\
\hline Perechyn district & 1 & - & - & - & - & - & - & - \\
\hline Svaliava district & 1 & - & - & - & - & - & - & - \\
\hline Tiachiv district & - & 2 & 2 & 1 & - & 4 & - & 1 \\
\hline Khust district & - & 1 & & 1 & - & - & - & 1 \\
\hline \multicolumn{9}{|c|}{ Mountain zone } \\
\hline $\begin{array}{l}\text { VelykyiBereznyi } \\
\text { district }\end{array}$ & - & 1 & - & - & - & - & - & - \\
\hline Volovets district & 1 & - & - & - & - & - & - & - \\
\hline Mizhhiria district & - & 1 & & - & - & - & - & - \\
\hline Rakhiv district & - & 1 & 2 & - & - & - & - & - \\
\hline
\end{tabular}

The following health care facilities, which provided specialized medical care were closed in the region in the period of 2014-2018: Uzhhorod District Hospital, Uzhhorod District Polyclinic and five district hospitals (three in Mukachevo district and two in Rakhiv district). During the same period, District Dental Polyclinic was opened in Tiachiv.

Outpatient care has the largest demand of all specialized medical care. Therefore, the next step of the study was to examine the planned capacity of outpatient polyclinics in terms across the region's administrative territories and geographical zones in the dynamics of 2014 and 2018. The data obtained are shown in Table. 4. 
Table 4

Planned capacity of outpatient polyclinics for specialized health care delivery in the context of administrative territories and geographical zones, 2014, 2018 (per 10,000 population)

\begin{tabular}{|c|c|c|c|}
\hline $\begin{array}{c}\text { Administrative territories, } \\
\text { geographical zones }\end{array}$ & $\mathbf{2 0 1 4}$ & $\mathbf{2 0 1 8}$ & $\mathbf{2 0 1 8}$ to 2014 \\
\hline \multicolumn{5}{|c|}{ Flatland zone } \\
\hline Uzhhorod city & 179 & 176 & -3 \\
\hline Berehove district & 194 & 190 & -4 \\
\hline Vynohradiv district & 192 & 184 & -8 \\
\hline Mukachevo district & 181 & 175 & -6 \\
\hline Uzhhorod district & 207 & 196 & \\
\hline \multicolumn{5}{|c|}{ Foothill zone } \\
\hline Irshava district & 248 & 244 & +17 \\
\hline Perechyn district & 211 & 228 & - \\
\hline Svaliava district & 157 & 157 & +1 \\
\hline Tiachiv district & 196 & 197 & +2 \\
\hline Khust district & 134 & 136 & -1 \\
\hline \multicolumn{5}{|c|}{ Mountain zone } \\
\hline VelykyiBereznyi district & 259 & 258 & -1 \\
\hline Volovets district & 197 & 196 & -2 \\
\hline Mizhhiria district & 196 & 194 & +2 \\
\hline Rakhiv district & 209 & 211 & \\
\hline
\end{tabular}

The analysis of the data presented in Table 4 indicates that there were no statistically significant differences in all administrative territories of the region in terms of planned outpatient clinics capacity for specialized medical care delivery in the period of 2014-2018.There is also no correlation between the geographical zone and the planned capacity for specialized medical care delivery of the outpatient clinics that function in that specific zone. At the same time, statistically significant differences were established in the planned outpatient clinics capacity for specialized medical care provision in different administrative territories. In Uzhhorod, the planned outpatient clinics capacity to provide specialized health care per 10,000 populations is 176 receptions per day. In terms of districts, the marginal difference of this rate is 1.90 times and ranges from 136 receptions in Khust district (foothill zone) to 258 in Velykyi Bereznyi district (mountain zone). This situation shows unequal access of the population from different administrative territories of the region to specialized outpatient care.

Further, the availability of hospital beds for the provision of specialized medical care was examined in the context of administrative territories and 
geographical zones. Comparisons were made between the availability of beds for specialized care in 2014 and 2018. The data obtained are shown in table 5.

Table 5

\section{Availability of hospital beds for specialized medical care in the context of administrative territories and geographical zones, 2014, 2018 (per 10,000 population)}

\begin{tabular}{|c|c|c|c|}
\hline $\begin{array}{c}\text { Administrative territories, } \\
\text { geographical zones }\end{array}$ & $\mathbf{2 0 1 4}$ & $\mathbf{2 0 1 8}$ & $\mathbf{2 0 1 8}$ to 2014 \\
\hline \multicolumn{5}{|c|}{ Flatland zone } \\
\hline Uzhhorod city & 54,55 & 55,50 & $+0,95$ \\
\hline Berehove district & 44,72 & 38,82 & $-5,90$ \\
\hline Vynohradiv district & 41,53 & 39,58 & $-1,95$ \\
\hline Mukachevo district & 45,45 & 28,23 & $-17,22$ \\
\hline Uzhhorod district & 18,65 & 38,45 & $+19,80$ \\
\hline \multicolumn{5}{|c|}{ Foothill zones } \\
\hline Irshava district & 40,64 & 39,76 & $-0,88$ \\
\hline Perechyn district & 39,81 & 38,19 & $-1,62$ \\
\hline Svaliava district & 45,36 & 40,90 & $-4,46$ \\
\hline Tiachiv district & 43,06 & 39,97 & $-3,09$ \\
\hline Khust district & 41,43 & 38,45 & $-2,98$ \\
\hline \multicolumn{5}{|c|}{ Mountain zone } \\
\hline VelykyiBereznyi district & 44,18 & 40,19 & $-3,99$ \\
\hline Volovets district & 46,96 & 47,26 & $+0,34$ \\
\hline Mizhhiria district & 42,96 & 43,30 & $+0,34$ \\
\hline Rakhiv district & 41,80 & 40,73 & $-1,07$ \\
\hline
\end{tabular}

The analysis of Table 4 data indicates the decrease of the hospital bed funds in health care institutions that provide inpatient specialized medical care in $10(71.43 \%)$ administrative territories during the observation period. The highest reduction rate (17.22 beds per 10 thousand population) was registered in Mukachevo district. At the same time, there was an increase in the hospital bed fund in $4(28.57 \%)$ administrative territories. The highest rate of increase (19.80 beds per 10 thousand population) was registered in Uzhhorod district.

The highest hospital bed number in institutions that provide specialized medical care was registered in Uzhhorod - 55.50 per 10 thousand population. There are statistically significant differences in the numbers of hospital beds in specialized medical care institutions in different districts. Thus, the marginal difference of these numbers is 1.67 times ranging from 28.23 in Mukachevo to 47.26 in Volovets districts. 
Besides, there are 25 highly specialized health care facilities in the region, which are the communal property of the regional administration. The highly specialized medical institutions of the region's health care include Transcarpathian Regional Clinical Hospital named after A. Novak, Regional Children's Hospital, Regional Psychiatric Hospital, Regional Clinical Infectious Diseases Hospital, Regional Territorial Medical Phthisiology Association Center, Transcarpathian Regional Clinical Oncology Center, Transcarpathian Regional Drug- and Alcohol-Addiction Center, Regional Hospital of War Veterans, Regional Clinical Center of Neurosurgery and Neurology, etc. These highly specialized medical care facilities have a total of 2,888 beds.

Also, there are other facilities in the region, such as the State Scientific and Practical Medical Rehabilitation Centre of the Ministry of Health of Ukraine and state owned Ukrainian Allergology Hospital.

\section{Characteristics of the regional medical care system personnel}

In total, the health care system of the Transcarpathian region employed 4408 physicians, amounting to 35.1 per 10 thousand population in 2018. Out of the total number of doctors, $70.6 \%$ were certified, including $72.3 \%$ with the highest certification category, $16.4 \%$ with the first certification category and $12.3 \%$ with the second certification category. The regional health care system also employed 9520 mid-level medical practitioners, i.e. 74.9 care providers per 10 thousand population. Out of the total number of mid-level medical care providers, $68.1 \%$ were certified, including $74.2 \%$ with the highest certification category, $14.5 \%$ with the first certification category and $12.1 \%$ with the second certification category.

The ratio of physicians and mid-level medical staff in the health system of the region was 1: 2.18, which is much lower than the WHO recommendations. As a result, doctors are overloaded and perform functions outside their purview.

We have also examined the availability of full-time positions of doctors (except for dentists) in health care facilities in the context of administrative territories and geographical zones in 2014 and 2018. The data obtained are given in Table. 6 .

The analysis of the data given in table 6 indicates that there was a slight tendency in 2018 compared to 2014 towards a reduction of doctors' positions in medical institutions in all administrative territories and geographical zones except Uzhhorod district, where an increase by 50.0 was registered. Most of the full-time positions of doctors are occupied except for Berehove district, where $28.66 \%$ of full-time positions are vacant, as well as Tiachiv and Khust districts, with $9.12 \%$ and $9.21 \%$ of vacant full-time positions respectively. The conducted 
analysis also makes it possible to conclude that not all doctors work full-time in the institutions of such administrative territories as Berehove, Mukachevo, Irshava, Tiachiv and Khust districts.

Table 6

Availability of full-time positions of doctors and their staffing in the health care system of the Transcarpathian region in the context of administrative territories and geographical zones, 2014, 2018

\begin{tabular}{|c|c|c|c|c|c|c|}
\hline \multirow[b]{2}{*}{$\begin{array}{c}\text { Administrative } \\
\text { territories, } \\
\text { geographical zones }\end{array}$} & \multicolumn{3}{|c|}{2014} & \multicolumn{3}{|c|}{2018} \\
\hline & $\stackrel{0}{:}$ & : & 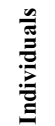 & $\stackrel{\varrho}{\stackrel{\Xi}{\varrho}}$ & 奇 & 芫 \\
\hline \multicolumn{6}{|c|}{ Flatland zone } & \\
\hline Uzhhorod city & 440,00 & 426,00 & 439 & 430,50 & 398,75 & 398 \\
\hline Berehove district & 207,25 & 175,00 & 187 & 206,75 & 147,50 & 155 \\
\hline Vynohradiv district & 283,25 & 264,75 & 245 & 287,00 & 262,25 & 245 \\
\hline Mukachevo district & 478,00 & 457,75 & 482 & 408,50 & 377,0 & 386 \\
\hline Uzhhorod district & 166,00 & 158,25 & 166 & 216,00 & 195,75 & 199 \\
\hline \multicolumn{7}{|c|}{ Foothill zone } \\
\hline Irshava district & 221,00 & 219,00 & 238 & 226,50 & 217,25 & 232 \\
\hline Perechyn district & 82,25 & 77,75 & 71 & 78,50 & 72,25 & 68 \\
\hline Svaliava district & 144,25 & 127,75 & 134 & 144,00 & 118,50 & 126 \\
\hline Tiachiv district & 434,00 & 409,50 & 435 & 419,25 & 381,00 & 400 \\
\hline Khust district & 320,75 & 303,50 & 332 & 331,00 & 300,50 & 321 \\
\hline \multicolumn{7}{|c|}{ Mountain zone } \\
\hline $\begin{array}{l}\text { VelykyiBereznyi } \\
\text { district }\end{array}$ & 65,50 & 63,50 & 64 & 64,50 & 61,25 & 61 \\
\hline Volovets district & 74,25 & 64,50 & 58 & 74,75 & 59,00 & 53 \\
\hline Mizhhiria district & 123,25 & 113,75 & 105 & 115,25 & 101,75 & 105 \\
\hline Rakhiv district & 228,50 & 218,50 & 203 & 229,75 & 216,75 & 199 \\
\hline
\end{tabular}

The data obtained during the research indicate that 1168.75 medical positions were introduced in healthcare institutions that deliver highly specialized medical care; among them 1093, 50 (93.60\%) were occupied by 986 physicians in 2018. In 2014, 1155.75 medical positions were introduced in healthcare institutions of highly specialized medical care; 1101.75 $(95.33 \%)$ of them were occupied by 1027 physicians. This situation indicates that there is a reduction in the number of medical positions, their staffing and the number of physicians working in highly specialized medical care institutions. 
Also, the availability of mid-level health care positions in medical facilities in administrative territories and geographical zones in 2014 and 2018 were studied. The data obtained are given in Table. 7.

Table 7

Availability of positions of mid-level medical workers and their staffing in the health care system of Transcarpathian region in the context of administrative territories and geographical zones in 2014, 2018

\begin{tabular}{|c|c|c|c|c|c|c|}
\hline \multirow[b]{2}{*}{$\begin{array}{c}\text { Administrative } \\
\text { territories, } \\
\text { geographical } \\
\text { zones }\end{array}$} & \multicolumn{3}{|c|}{2014} & \multicolumn{3}{|c|}{2018} \\
\hline & $\frac{n}{b}$ & : & 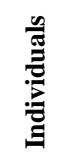 & $\stackrel{n}{: 0}$ & : & $\frac{n}{\underline{E}}$ \\
\hline \multicolumn{6}{|c|}{ Flatland zone } & \\
\hline Uzhhorod city & 671,75 & 647,75 & 669 & 665,25 & 612,25 & 614 \\
\hline Berehove district & 443,25 & 402,25 & 483 & 412,75 & 318,75 & 345 \\
\hline $\begin{array}{c}\text { Vynohradiv } \\
\text { district }\end{array}$ & 671,50 & 646,75 & 773 & 675,25 & 610,50 & 678 \\
\hline $\begin{array}{c}\text { Mukachevo } \\
\text { district }\end{array}$ & 989,00 & 955,75 & 1085 & 790,50 & 755,50 & 845 \\
\hline Uzhhorod district & 278,25 & 253,00 & 247 & 357,00 & 275,25 & 270 \\
\hline \multicolumn{7}{|c|}{ Foothill zone } \\
\hline Irshava district & 634,50 & 632,25 & 911 & 599,75 & 584,25 & 816 \\
\hline Perechyn district & 167,75 & 162,50 & 169 & 149,50 & 137,75 & 136 \\
\hline Svaliava district & 289,25 & 286,75 & 409 & 281,25 & 256,00 & 340 \\
\hline Tiachiv district & 947,75 & 938,25 & 1165 & 860,25 & 804,25 & 976 \\
\hline Khust district & 663,25 & 655,75 & 830 & 674,75 & 659,25 & 774 \\
\hline \multicolumn{7}{|c|}{ Mountain zone } \\
\hline $\begin{array}{c}\text { VelykyiBereznyi } \\
\text { district }\end{array}$ & 155,50 & 154,50 & 165 & 157,25 & 152,75 & 160 \\
\hline Volovets district & 173,25 & 167,50 & 200 & 173,50 & 164,00 & 193 \\
\hline Mizhhiria district & 291,50 & 287,00 & 340 & 287,50 & 277,50 & 329 \\
\hline Rakhiv district & 481,50 & 463,00 & 548 & 485,00 & 441,00 & 510 \\
\hline
\end{tabular}

The analysis of the data presented in Table 7 indicates the stability of full-time positions of mid-level medical staff and their staffing in the healthcare system of the Transcarpathian region. The exception is Tiachiv district where the number of mid-level medical staff positions reduced by $87.50(9.23 \%)$ during the period of five years (2014-2018). At the same time, in Uzhhorod district the number of mid-level medical staff positions increased by 78, 25 (28.30\%) during the period of five years (2014-2018). 
Besides, 2399.50 positions of mid-level medical staff were introduced in health care institutions of highly specialized medical care. $2311(96.31 \%)$ of them were occupied, employing 2386 mid-level medical care providers in 2018. In 2014, 2355.50 mid-level medical staff positions were occupied in health care institutions of highly specialized medical care employing 2465 individuals, thus filling $97.17 \%$ of positions. This emphasizes that mid-level medical staff in highly specialized medical healthcare institutions in the region was preserved.

Taking into account the importance of mid-level medical staff in medical care delivery, we further analyzed the supply of mid-level medical staff in health care facilities of primary and specialized medical care per 10 thousand population in the context of administrative territories and geographical zones in 2014 and 2018. The data obtained are given in Table. 8.

Table 8

Supply of mid-level medical staff in health care facilities of primary and specialized medical care in the context of administrative territories and geographical zones in 2014, 2018 (per 10 thousand population)

\begin{tabular}{|c|c|c|c|c|c|c|}
\hline \multirow[b]{2}{*}{$\begin{array}{l}\text { Administrative } \\
\text { territories, } \\
\text { geographical } \\
\text { zones }\end{array}$} & \multicolumn{3}{|c|}{2014} & \multicolumn{3}{|c|}{2018} \\
\hline & $\stackrel{a}{a}$ & 苞 & 这 & $\stackrel{0}{0}$ & 苞 & 芫起 \\
\hline \multicolumn{6}{|c|}{ Flatland zone } & \\
\hline Uzhhorod city & 58,73 & 56,63 & 58,49 & 59,17 & 54,45 & 54,61 \\
\hline Berehove district & 58,30 & 52,91 & 63,53 & 55,44 & 42,81 & 46,34 \\
\hline $\begin{array}{c}\text { Vynohradiv } \\
\text { district }\end{array}$ & 55,77 & 53,72 & 64,20 & 55,68 & 50,34 & 55,91 \\
\hline $\begin{array}{c}\text { Mukachevo } \\
\text { district }\end{array}$ & 53,19 & 51,40 & 58,35 & 42,59 & 40,70 & 45,52 \\
\hline Uzhhorod district & 35,30 & 32,09 & 31,33 & 49,82 & 38,41 & 37,68 \\
\hline \multicolumn{7}{|c|}{ Foothill zone } \\
\hline Irshava district & 63,67 & 63,45 & 91,42 & 59,61 & 58,07 & 81,10 \\
\hline Perechyn district & 52,59 & 50,94 & 52,98 & 46,42 & 42,77 & 42,23 \\
\hline Svaliava district & 53,55 & 53,09 & 75,73 & 52,06 & 47,38 & 62,93 \\
\hline Tiachiv district & 54,42 & 53,87 & 66,89 & 49,12 & 45,92 & 55,73 \\
\hline Khust district & 52,04 & 51,45 & 65,12 & 52,95 & 51,73 & 60,74 \\
\hline \multicolumn{7}{|c|}{ Mountain zone } \\
\hline $\begin{array}{c}\text { VelykyiBereznyi } \\
\text { district }\end{array}$ & 58,22 & 57,84 & 61,77 & 59,07 & 57,38 & 60,10 \\
\hline Volovets district & 70,74 & 68,39 & 81,66 & 71,31 & 67,40 & 79,32 \\
\hline Mizhhiria district & 60,79 & 59,85 & 70,90 & 60,44 & 58,34 & 69,16 \\
\hline Rakhiv district & 52,28 & 50,27 & 59,50 & 52,12 & 47,39 & 54,81 \\
\hline
\end{tabular}


The analysis of the data given in table 8 indicates that the supply of midlevel medical staff in the primary and specialized health care facilities per 10 thousand people in administrative territories is statistically significant and fluctuates 1.67 times. Thus, the lowest supply of mid-level medical staff (42.59) was registered in Mukachevo district and the highest (71.31) in Volovets district.

In general, the supply of mid-level medical staff is highest in the mountainous areas in terms of geographical zones.

The rate of mid-level medical staff in the Transcarpathian region as a whole decreased from 73.47 to 71.69 per 10 thousand population (by 1.78 positions for every 10 thousand people) in the period from 2014 to 2018. At the same time, none of the positions in 15 (5.77\%) FeldscherMidwife units out of total 260 is occupied by a medical professional.

In order to provide a comprehensive understanding of the health care of the region we have researched and presented data on the system of emergency medical care provided to the population. The obtained data are presented in table 9. The Transcarpathian Territorial Center of Emergency Medical Care (TTCEMC) carries out the organization of emergency medical care in the region. There are 14 emergency medical care units in the region, which employ 154 doctors and 589 junior specialists with medical education.

Table 9

Emergency medical service network and staff of the Transcarpathian region, 2018

\begin{tabular}{|c|c|c|c|c|c|c|c|}
\hline \multirow[b]{2}{*}{$\begin{array}{l}\text { Administrative } \\
\text { territories }\end{array}$} & \multirow[b]{2}{*}{$\begin{array}{c}\text { Total } \\
\text { positions }\end{array}$} & \multicolumn{3}{|c|}{ Positions of physicians } & \multicolumn{3}{|c|}{$\begin{array}{c}\text { Positions of mid-level medical } \\
\text { staff }\end{array}$} \\
\hline & & 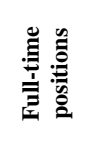 & 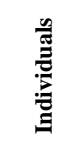 & 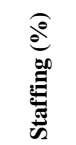 & 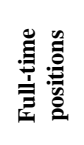 & 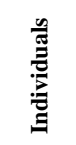 & 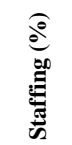 \\
\hline 1 & 2 & 3 & 4 & 5 & 6 & 7 & 8 \\
\hline $\begin{array}{c}\text { Transcarpathian } \\
\text { regional center of } \\
\text { emergency } \\
\text { medical care }\end{array}$ & 1325,75 & 180,75 & 154,00 & 85,20 & 544,50 & 589,00 & 96,87 \\
\hline \multicolumn{8}{|c|}{ Emergency medical care units } \\
\hline district & 60,50 & 5,50 & 4,00 & 72,73 & 28,00 & 27,00 & 96,43 \\
\hline $\begin{array}{l}\text { VelykyiBereznyi } \\
\text { district }\end{array}$ & 42,00 & 4,50 & 4,00 & 88,89 & 22,50 & 22,00 & 97,78 \\
\hline $\begin{array}{c}\text { Vynohradiv } \\
\text { district }\end{array}$ & 88,50 & 5,50 & 4,00 & 72,73 & 41,50 & 48,00 & 100,0 \\
\hline Volovets district & 35,50 & 5,50 & 4,00 & 72,73 & 13,50 & 14,00 & 100,0 \\
\hline Irshava district & 90,25 & 5,50 & 4,00 & 72,73 & 42,25 & 44,00 & 100,0 \\
\hline
\end{tabular}


Continuation of Table 9

\begin{tabular}{|c|c|c|c|c|c|c|c|}
\hline $\mathbf{1}$ & $\mathbf{2}$ & $\mathbf{3}$ & $\mathbf{4}$ & $\mathbf{5}$ & $\mathbf{6}$ & $\mathbf{7}$ & $\mathbf{8}$ \\
\hline Mizhhiria district & 82,50 & 5,50 & 4,00 & 72,73 & 36,75 & 47,00 & 100,0 \\
\hline $\begin{array}{c}\text { Mukachevo } \\
\text { district }\end{array}$ & 204,50 & 37,00 & 36,00 & 97,30 & 82,50 & 95,00 & 100,0 \\
\hline Perechyn district & 43,50 & 5,50 & 5,00 & 90,91 & 18,00 & 16,00 & 88,89 \\
\hline Rakhiv district & 72,50 & 5,50 & 5,00 & 100 & 35,00 & 31,00 & 88,57 \\
\hline Svaliava district & 41,50 & 5,50 & 3,00 & 54,55 & 18,00 & 19,00 & 100,0 \\
\hline Tiachiv district & 160,00 & 5,50 & 5,00 & 90,91 & 72,50 & 89,00 & 100,0 \\
\hline Uzhhorod district & 77,50 & 18,50 & 13,00 & 70,27 & 27,00 & 26,00 & 96,30 \\
\hline Khust district & 81,00 & 11,00 & 10,00 & 90,91 & 36,50 & 37,00 & 100,0 \\
\hline Uzhhorod & 164,25 & 45,50 & 42,00 & 92,31 & 47,00 & 54,00 & 100,0 \\
\hline $\begin{array}{c}\text { Administrative } \\
\text { and managerial } \\
\text { staff }\end{array}$ & 81,75 & 15,25 & 11,00 & 72,13 & 23,50 & 20,00 & 85,11 \\
\hline
\end{tabular}

\section{CONCLUSIONS}

The conducted analysis of the health care institutions network and health care personnel in the Transcarpathian region showed that there are 646 health care facilities and separate structural divisions in the region, of which $91.18 \%$ provide primary care, $4.95 \%$ provide specialized and $3.87 \%$ highly specialized medical care. Besides, there is an emergency medical care unit in each administrative territory.

The planned capacity of outpatient clinics for providing specialized medical care and the availability of hospital beds have statistically significant differences in the context of administrative zones.

Statistically significant differences were also established in the supply of medical staff in the context of administrative territories. At the same time, a common problem for all administrative territories is the tendency towards a reduction of the positions and low ratio of physicians and mid-level medical staff; as a result, physicians perform functions outside their purview.

\section{SUMMARY}

The conducted analysis of the health care institutions network and health care personnel in the Transcarpathian region showed that there are 646 health care facilities and separate structural divisions in the region, of which $91.18 \%$ provide primary care, $4.95 \%$ provide specialized and $3.87 \%$ highly specialized medical care. Besides, there is an emergency medical care unit in each administrative territory.

The planned capacity of outpatient clinics to provide specialized medical care and the availability of hospital beds have statistically significant differences in the context of administrative zones.

The availability of hospital beds for specialized inpatient care in the districts fluctuates 1.67 times: from 28.23 in Mukachevo district to 47.26 in 
Volovets district, whereas there are 55.50 beds per 10 thousand population in Uzhhorod. At the same time, highly specialized medical care facilities have a total of 2,888 beds.

The article shows that the Transcarpathian health care system employed 4408 physicians (without managerial staff and dentists), which accounted for 35.1 per 10 thousand population in 2018. Out of the total number of doctors, $70.6 \%$ were certified, including $72.3 \%$ with the highest certification category, $16.4 \%$ with the first certification category and $12.3 \%$ with the second certification category. The health care system of the region also employed 9520 mid-level medical staff, i.e. 74.9 per 10 thousand population. Out of the total number of mid-level medical staff, $68.1 \%$ were certified, including $74.2 \%$ with the highest certification category, $14.5 \%$ with the first certification category and $12.1 \%$ with the second certification category.

Statistically significant differences were also established in the supply of medical staff in the context of administrative territories. At the same time, a common problem for all administrative territories is the tendency towards a reduction of staff positions and low ratio of physicians and mid-level medical staff.

\section{REFERENCES}

1. Stratehichna doradcha hrupa z pytan reformuvannia systemy okhorony zdorovia v Ukraini (2015) Natsionalna stratehiia reformuvannia systemy okhorony zdorovia v Ukraini na period 2015-2020 rokiv [National Health Care Reform Strategy in Ukraine for the period of 2015-2020], pp. 41. Retrived from: http://healthsag.org.ua/strategiya/

2. Lekhan V.M., Slabkyi H.O., Shevchenko M.V. (2015) Analiz rezultativ reformuvannia systemy okhorony zdorovia $\mathrm{v}$ pilotnykh rehionakh: pozytyvni naslidky, problemy ta mozhlyvi shliakhy yikh vyrishennia [Analyzing health reform outcomes in pilot regions: positive impacts, challenges, and possible solutions]. Zdorovia Natsii, vol. 3 (Special issue), pp. 67-86.

3. Slabkyi H.O., Lekhan V.M. (2015) Uroky reformy okhorony zdorovia v Ukraini: dosiahnennia, nevyrisheni pytannia, ryzyky, problemy [Healthcare reform lessons in Ukraine: achievements, unresolved issues, risks, challenges]. Proceedings of the International Conference "Orhanizatsiia i upravlinnia okhoronoiu zdorovia" (Ukraine, October 20-21, 2015), pp. 26-27.

4. Slabkyi H. O., Zozulia I.S., Zozulia A.I. (2014) Priorytetnyi rozvytok pervynnoi medyko-sanitarnoi dopomohy na zasadakh simeinoi medytsyny 
[Priority development of primary health care based on family medicine]. Simeina medytsyna, vol. 3, No. 53, pp. 25-27.

5. Lekhan V. M., Nadutyi K.O., Slabkyi H.O. (2011) Innovatsiini pidkhody do zabezpechennia dostupnosti pervynnoi medyko-sanitarnoi dopomohy silskomu naselenniu [Innovative approaches to ensuring the availability of primary health care to the rural population]. Zdorovia natsii, vol. 3, No. 19, pp. 86-91.

6. Matiukha L.F., Lekhan V.M., Hoida N.H. et al. (2011) Poriadok orhanizatsii nadannia medychnoi dopomohy ta zabezpechennia marshrutiv patsiienta likarem zahalnoi praktyky - simeinym likarem pry riznykh klinichnykh stanakh ta zakhvoriuvanniakh [The procedure for the organization of care and providing pathways by a general practitioner family physician in different clinical conditions and diseases]. Ministry of Health of Ukraine; National Medical Academy of Post-Graduate Education named after P. L. Shupyk, Ukrainian Institute for Social Research, Dnipropetrovsk State Medical Academy, Zaporizzhia Medical PostGraduate Academy, Chernivtsi Health Care Department, p. 43.

7. Parkhomenko H. Ya. (2011) Likarnia intensyvnoi dopomohy likarnia yevropeiskoho zrazka [Intensive care hospital - a European-style hospital]. Visnyk sotsialnoi hihiieny ta orhanizatsii okhorony zdorovia Ukrainy, vol. 2, pp. 39-41.

8. Kotenko S.L. (2015) Derzhavne rehuliuvannia kadrovoi polityky haluzi okhorony zdorovia [State regulation of the personnel policy of the health care industry]. Proceedings of the Conference "Zavdannia derzhavy $\mathrm{u}$ zabezpechenni efektyvnoi kadrovoi polityky systemy okhorony zdorovia" (Ukraine, Kyiv, April 22, 2015), pp. 56-59.

9. Zakon Ukrainy vid 19 zhovtnia 2017 roku 2168-VIII (2017) Pro derzhavni finansovi harantii medychnoho obsluhovuvannia naselennia [Law of Ukraine On State Financial Guarantees of Public Health Services: Law of Ukraine of October 19, 2017 No. 2168-VIII]. Retrieved from: http://search.ligazakon.ua/l_doc2.nsf/link1/T172168.html

10. Skryp V. V., Slabkyi H.O. (2015) Metodychni pidkhody do avtonomizatsii zakladiv okhorony zdorovia [Methodological approaches to the autonomy of health care institutions]. Intermedical Journal, vol. IV, No. 6, pp. 20-25.

11. Rohach I.M., Danko D.V. (2019) Kharakterystyka naselennia Zakarpatskoi oblasti [Characteristics of the population of the Transcarpathian region]. Ekonomika i pravo okhorony zdorovia, vol. 1, No. 9, pp. 75-78. 
12. Zakarpatskyi oblasnyi medychnyi informatsiino-analitychnyi tsentr (2015) Merezha zakladiv ta osnovni pokaznyky diialnosti systemy okhorony zdorovia Zakarpatskoi oblasti za 2014 rik. [Network of institutions and key indicators of health care system activity in Transcarpathian region for 2014] Uzhhorod: Zakarpatskyi oblasnyi medychnyi informatsiino-analitychnyi tsentr.

13. Zakarpatskyi oblasnyi medychnyi informatsiino-analitychnyi tsentr (2019) Merezha zakladiv ta osnovni pokaznyky diialnosti systemy okhorony zdorovia Zakarpatskoi oblasti za 2018 rik [The network of institutions and key indicators of the health care system of Transcarpathian region for 2018] Uzhhorod: Zakarpatskyi oblasnyi medychnyi informatsiino-analitychnyi tsentr.

Information about the author: Danko D. V., orcid.org/0000-0003-2992-5333 Associate Professor at the Department of Social Medicine and Hygiene Uzhhorod National University 1, Narodna Sq., 88000, Uzhhorod, Ukraine 